\title{
Prolactin and the physiological regulation of its secretion. A review
}

\author{
M. Ciechanowska ${ }^{1,3}$, T. Misztal $^{2}$ and F. Przekop ${ }^{2}$ \\ ${ }^{1}$ The General Karol Kaczkowski Military Institute of Hygiene and Epidemiology, \\ Department of Pharmacology and Toxicology \\ Kozielska 4, 01-163 Warsaw, Poland \\ ${ }^{2}$ The Kielanowski Institute of Animal Physiology and Nutrition, Polish Academy of Sciences,
}

05-110 Jabłonna, Poland

KEY WORDS: lactotrophs localization, PRL release, dopamine, salsolinol, rat, sheep

Received: 29 January 2013

Revised: 18 April 2013

Accepted: 7 June 2013

${ }^{3}$ Corresponding author: e-mail: mciechanowska@wihe.waw.pl

\begin{abstract}
This review briefly summarizes recent findings on lactotrophs in the pituitary gland and extrapituitary tissues as a no homologous group cell types of different embryonic origin, morphology and biological function. They display a remarkable adaptation to altered physiological condition. Their functions are derived from structural polymorphism, local synthesis, divergent intracellular signaling pathways and target genes. Most of them are heterogenous with respect to basal hormone release, electrical activity and responsiveness to stimulatory/inhibitory factors, depending upon gender and physiological state of animal. The circulating prolactin (PRL) produced by many types of lactotrophs can act in edocrine/paracrine/autocrine manner, respectively as a hormone, growth factor, neurotransmitter or immunoregulator. At the cellular level PRL exerts mitogenic, morphogenic and secretory activity. Numerous factors of the central and peripheral origin are involved in the mechanism regulating PRL secretion, causing an increase or decrease of the hormone concentration in the circulation. The certain feedback mechanism keep the pituitary lactotrophs to be not overactive.
\end{abstract}

\section{Introduction}

Prolactin (PRL) is an anterior pituitary hormone, which together with the growth hormone (GH) and placental lactogens (PLs) form a family of hormones that probably result from the duplication of an ancestral gene (Cooke et al., 1981; Miller and Eberhardt, 1983; Walker et al., 1991). PLs, which are found only in mammals have presumably an alternative genetic origin, either GH lineage in primate or the PRL lineage in nonprimate animals (Miller and Eberhardt, 1983; Walker et al., 1991).

PRL is a single-chain protein of 197 aminoacids (AA) in rats and mice and 199 AA in human, sheep, pigs and cows (Freeman et al., 2000). Recent studies indicate that it is synthetized and released by lactotrophs which represent $25-50 \%$ of the pituitary cells (Ben-Jonathan et al., 1996). With the exception of fish, all indentified PRLs isoforms contain six cysteines that forming three intracellular disulphide bonds (Bole-Feysot et al., 1998). The fish PRLs are shorter than mammals PRLs and lack a dozen residues at $\mathrm{N}$-amino-terminal domain including the first di-sulphide bridge (Rentier-Delrue et al., 1989). In tilapia, two distinct PRL forms have been isolated which differ by the length, composition and their biological activities (Rentier-Delrue et al., 1989). The PRL sequences from taxonomi- 
cally distant vertebrate species show a high degree of divergence (Yasuda et al., 1987). Studies on the secondary structure of PRL have shown, that PRL is an all- $\alpha$-heliks protein and contains about $50 \%$ of $\alpha$-helices (Bewley and Li, 1972; Bole-Feysot et al., 1998), while the remainder of the proteins appear to fold into nonorganized loop structures. Human PRL tertiary structure is predicted to fold in a four-helix bundle (Bole-Feysot et al., 1998).

Many variants of PRL, which have been identified in mammals, can be formed theoretically by post-transcriptional processing of primary transcript and/or post-translational modification of protein (Ben-Jonathan et al., 1996). It is well recognized that circulating PRL may exist in little form (monomeric), big form and big-big form (macroprolactin), with molecular masses of 23, 50 and $150-170 \mathrm{kDa}$, respectively (Diver et al., 2001; Fahie-Wilson et al., 2005; Galoiu et al., 2005; Ellis et al., 2007). Generally, only some big forms retain PRL-like activity, but others have unique properties or no known functions (Sinha, 1995). Monomeric form of PRL which normally is up $85-90 \%$ of serum prolactin, big PRL form $<10 \%$, and big-big prolactin $<3 \%$ (Galoiu et al., 2005). However, in some humans, the big-big form variant represents the majority of circulating PRL (Jackson et al., 1985).

Big prolactin is a complex of little PRL and another serum components, possible prolactin-binding protein or represents a dimmer of little prolactin (Kline and Clevenger 2001; Piketly et al., 2002). The big-big prolactin was identified mainly as a high stability complex of peripheral origin from monomeric prolactin of any source (pituitary or extrapituitary) and immunoglobulin G (Hattori et al., 1992; Bonhoff et al., 1995; Cavaco et al., 1995). Because of its low clearance macroprolactinaemia determines high level of PRL with normal pituitary function (Galoiu et al., 2005). Most frequent causes of high levels of PRL are pituitary tumors, drugs and hypothyroidism. It is more frequent in patients with autoimmune diseases, such as synthesis lupus erythematosus (Ahlquist et al., 1998; Leanos et al., 1998; Pacilio et al., 2001). Macroprolactin appears to have negligible bioactivity at human prolactin receptor in vivo, but in vitro it seems that it has normal biological activity (Leite et al., 1992; Galoiu et al., 2005).

There are also smaller molecular mass variants of PRL, which are produced by proteolytic cleavage, both at the sites of synthesis or at some target tissues (Casabiell et al., 1989; Powers and Hatala, 1990; Baldocchi et al., 1992; DeVito et al., 1992; Ben-Jonathan et al., 1996). For example, the 22$\mathrm{kDa}$ form PRL-1-173 is generated by kallikrein a trypsyn-like serine protease that is aboundant in lactotrophs (Powers and Hatala, 1990). The production of this form is sex-dependent and is stimulated by oestrogen and suppressed by dopamine (Anthony et al., 1993). It is likely, that PRL-1-173 plays a potential role in female reproduction.

The 16-kDA PRL binds weakly to PRL receptors and its antiangiogenic activity, shown in vivo and in vitro, is mediated by high affinity receptor distinct from PRL receptors (Clapp and Weiner, 1992). The 16-kDa PRL formation proceeds in two steps: cleavage by a cathepsin D-like protease, which generates a two-chain molecule joined by a disulphide bond followed by a reduction yielding $16-\mathrm{kDa}$ and $8-\mathrm{kDa}$ fragments. The $16-\mathrm{kDa}$ has been detected in the hypothalamus, pituitary and serum, accounting for about $1 \%$ of the total secreted PRL (Ben-Jonathan et al., 1996). The variants of PRL with molecular sizes $8,16,24-\mathrm{kDa}$ were found in the hypothalamus of rats, and variants ranging from 11 to 46 were identified in the human lymphocytes (Ben-Jonathan et al., 1996).

Prolactin variants, ranging from 14 to $<90 \mathrm{kDa}$, released in vitro from the pituitary of lactating, pregnant and steroid-treated female or male rats stimulates PRL secretion from pituitary lactotrophs of male rats (Mena et al., 2010). The main effects on PRL release are provoked by the 23 to $46 \mathrm{kDa}$ PRL variants (Mena et al., 2010). Glycosylated PRL is detected in pituitary and plasma, composing $1 \%$, $15 \%$ and $50 \%$ of total PRL in bovine, human and porcine pituitaries, respectively (Sinha, 1995).

There is evidence for constitutive, rather than regulated, secretion of glycosylated PRL (Ben-Jonathan et al., 1996). It varies among species and their heterogeneity accounts for differences in bioactivity, immunoreactivity, receptor bindings and often decreases PRL bioactivity (Ben-Jonathan et al., 1996; Mena et al., 2010).

\section{Pituitary and extrapituitary producing cells}

The lactotroph cells of the pituitary gland are non-homologous group of cells; these cells can be separate into subsequent subpopulation based on morphological criteria: density granulated cells that function as storage or resting cells and sparsely granulated secretory cells that are particularly abundant in prolactinomas (Ben-Jonathan et al., 1996). Functionally, lactotrophs are also heterogeneous with respect to basal hormone release, electrical activity and responsiveness to releasing inhibitory factors, including regional differences in exposure to hypothalamic or posterior pituitary factors (BenJonathan et al., 1996; Mena et al., 2010). 
In rodents, the three morphological types of lactotrophs have been defined by electron microscopy (Christian et al., 2007). Type I 'classical lactotrophs' contain large irregular shaped electro-dense secretory granules (diameter 300-700 nm), type II cells contain numerous sized spherical electron dense granules (diameter 200-250 nm), and type III cells, which have small (100-200 nm) spherical granules. In male and female young rats of 10 days of age the majority of lactotrophs in pituitary are type III, by 30 days of age, the lactotrophs population comprises mostly type II cells, at 60 days of age, the proportion of PRL cell types in male pituitary changes significantly (approximately 40\% type I, 50\% type II, $10 \%$ type III cells) compared to females (80-90\% type I, $10-20 \%$ type II, $2-4 \%$ type III). Although differentiation of these types of lactotrophs is not known, it is suggested that they might represent different stages of cell maturation. So, the function of lactotrophs is derived from structural polymorphism, local synthesis, divergent intracellular signaling pathways and target tissue (Ben-Jonathan et al., 1996; Stojilkovic et al., 2010). Indeed clonal cell line $\mathrm{GH}_{3}$ produced prolactin and growth hormone and express thyrotropin releasing hormone (TRH), vasoactive intestinal polypeptide (VIP) and epidermal growth factor receptors, but not dopamine (DA) receptors (Ben-Jonathan et al., 1996; Stojilkovic et al., 2010). The 235-1 lactotroph cell line express the PRL gene. They secrete PRL in $\mathrm{CA}^{++}$-dependent manner. Similarly, the MMQ cells (a unique prolactin-secreting rat pituitary cell line) secrete prolactin only in a $\mathrm{CA}^{++}$-dependent manner and express functionally DA-D receptor, endothelin receptor (ETa) and oxytocin receptor (Stojilkovic et al., 2010). The PRL that is produced by different cell types can act in direct fashion as a growth factor, neurotransmitter or immunomodulator in auto or paracrine manner (Bole-Feysot et al., 1998).

The PRL is involved in many (more than 300) biological function, including water and electrolyte balance, growth and development, endocrinology and metabolism, brain function and behaviour, reproduction, immunoregulation and protection and also its action associated with pathological disease state (Bole-Feysot et al., 1998).

Besides of the pituitary lactotrophs, PRL gene expression has been detected in many extrapituitary PRL producing cells: in various region in the brain, decidua, myometrium lacrimal gland, thymus, spleen, circulating lymphocytes and lymphoid cells from marrow, mammary epithelial cells and tumor, skin fibroblasts and sweet glands (Ben-Jonathan et al., 1996; Bole-Feysot et al., 1998).
The hypophysectomized rats, just after hypophysectomy, retain about $20 \%$ of biologically active form of PRL in blood, which increases to approximately to $50 \%$ in normal level with time (Nagy and Berczi, 1991; Bole-Feysot et al., 1998). Neutralization of circulating PRL with PRL-antibodies results in immune disfunction and death of animals indicating that extrapituitary PRL can compensate for pituitary PRL (Nagy and Berczi, 1991).

\section{Factors inhibiting prolactin secretion}

Different morphological subtypes of lactotrophs display differential secretory activity in response to various stimulatory and inhibitory factors.

Consistent with a high basal level of PRL secretion from a pituitary gland, the predominant hypothalamic influence on PRL release is inhibitory rather than stimulatory and is mainly exerted by a neurotransmitter DA, acting through the DA-D membrane receptors, which are coupled with Gi/o signaling pathway (Ben-Jonathan and Hnasko, 2001). DA inhibits PRL release decreasing the cytosolic free calcium concentration (Lambert and Macleod, 1990) and suppresses PRL mRNA level (Ben-Jonathan and Hnasko, 2001). This inhibitory effect of DA on PRL secretion is exerted principally by reducing intracellular phospholipase signaling pathway and/or pituitary-specific transcription factor Pit-1 (Caccavelli et al., 1992; Lew and Elsholtz, 1995; Ben-Jonathan and Hnasko, 2001). In rats, DA reaches the lactotrophs in the anterior lobe of the pituitary gland from each 3 hypothalamic dopaminergic systems: the tuberoinfundibular (TIDA), tuberohypophyseal (THDA) and periventricular hypophyseal (PHDA) DA cells (De Maria et al., 1998; Freeman et al., 2000).

The TIDA neurons arise from the dorsomedial arcuate nucleus and their axons terminate in the capillary bed of the external zone of the median eminence (ME), where DA diffuses and is transported to the anterior pituitary via long portal vessels. THDA neurons arise from the rostral arcuate nucleus, and their axons terminate on short portal vessels in the neural lobe and intermediate lobe of pituitary. PHDA neurons arise from the periventricular nucleus, and their axons terminate exclusively on short portal vessels in the intermediate lobe (Poletini et al., 2010).

Dopamine binds to DA-D2 receptors on lactotrophs that are functionally linked to membrane channels and $G$ proteins and suppresses the high secretory activity of these cells. A definite increase in PRL secretion occurs following lactotrophs escape from the inhibitory hypothalamic dopaminer- 
gic tone. Once PRL has been secreted, it feeds back on the hypothalamus to stimulate the synthesis and turnover of DA, as well as to promote the release of DA into pituitary portal blood (Poletini et al., 2010). The action of DA on the PRL secretion is timedependent. Indeed, within seconds, DA increases potassium conductance and inactivates voltagesensitive calcium channels, resulting in membrane hyperpolarization and lowering the intracellular free calcium; within minutes to hours, DA decreases adenylcyclase activity, inosytol phosphate metabolism, arachidonic acid release and PRL gene expression. Within days, DA suppresses PRL cell proliferation (Stojilkovic et al., 2010). Withdrawal of DA after short application evokes a rapid rebound increase of basal PRL secretion (Ben-Jonathan and Hnasko, 2001). DA actions in lactotrophs depend on the gonadal steroid milieu in female rats. Oestrogen decreases the expression of DA-D2 receptors and number of Gi/o immunoreactive lactotrophs (Livingstone et al., 1998; Stojilkovic et al., 2010). Also the stimulatory and inhibitory actions of DA on PRL release vary throughout the oestrous cycle and in the ovariectomized rats with the steroid replacement therapy (Stojilkovic et al., 2010). On the other hand, in vivo experiments often yield conflicting results because prolonged exposure and high doses of oestradiol increases PRL release, PRL gene expression and number of lactotrophs by activating PRL short loop feedback mechanism. Also a rapid rebound of PRL secretion after withdrawal of DA is steroid-dependent (Ben-Jonathan and Hnasko, 2001; Sam and Frohman, 2008).

Endothelin peptides, which are differentially expressed in tissues of the peripheral and central nervous system, have profound effects on prolactin secretion (Samson et al., 1990; Kanyicska et al., 1991; Samson and Skala, 1992; Kanyicska et al., 1995; Stojilkovic et al., 2010). The endothelin receptors ETa are located on the lactotrophs (Stojilkovic et al., 2010). Stimulation of these receptors transiently activates PRL release followed sustaining inhibition; in lactotrophs the inhibitory phase lasts for several hours. Interestingly, DA could also change the number of ETa receptors signals from inhibitory to stimulatory. ETa receptors might recouple to the inhibitory pathways coupled to DAD2 receptors and thus ETs might replace DA as the primary inhibitory factor (Stojilkovic et al., 2010).

Arginin-vasopresin peptide, which is synthesized in the dorsomedial portion of suprachiasmatic nucleus (SCN) (Moore et al., 2002; Morin et al., 2006) displays an inhibitory role on PRL secretion induced by oestradiol in female rats (Palm et al., 2001).
Other neuropeptides, such bombesin like peptides, neurotensin, NPY inhibit PRL release by stimulating the TIDA neurons (Ben-Jonathan and Hnasko, 2001). Their actions are often confounded by their ability to exert opposite effect on the pituitary lactotrophs. More specifically, bombesin-like peptides (neuromedins $\mathrm{B}$ and $\mathrm{C}$, and ranatensin) may also play a role in the circadian rhythm of PRL release, acting via the SCN (Mai and Pan, 1995). The central immunoneutralization of these peptides is provided by the rise in serum PRL (Ben-Jonathan and Hnasko, 2001).

Neurotensin, like many neuropeptides, exerts a dual action on PRL: the central inhibition and peripheral stimulation (Pan et al., 1992). Neurotensin centrally stimulates TIDA neurons and decreases in serum PRL (McCann and Vijayan, 1992). The influence of NPY, the most abundant neuropeptide in the brain, on PRL release is similar to those of neurotensin, except that it does not mediate the PRL feedback effect on TIDA neurons (Freeman et al., 2000). In MMQ cells of rats oestradiol increases the expression of DA-D2 receptors and might decrease PRL release (Stojilkovic et al., 2010).

Current studies have revealed that anorectic and orexigenic hormones participate also in the control of prolactin secretion, although potential mechanisms account these processes are still not resolved. The results indicate that effect of leptin on PRL release may be species-specific. It has been noted that leptin mediated the stimulation of PRL release in bovine adenohypophyseal explants in culture (Accorsi et al., 2007) but it had little effect on PRL secretion from primary culture of porcine anterior pituitary cells (Nonaka et al., 2007). Circulating PRL increase in response to leptin treatment in rats and it is suggested that this effect is mediated by hypothalamic neurons as well as in direct inhibition of PRL release from pituitary gland (Yu et al., 1997; Gonzalez et al., 1999; Watanobe et al., 1999). In sheep, seasonally breeding species, leptin can modulate PRL release from pituitary gland in vitro and its effect on PRL release is seasonally dependent (Zięba et al., 2008). Centrally infused leptin decreased mean concentration of PRL slightly during short day and increased this hormone secretion during long photoperiod. Based on the foregoing results on sheep it is suggested that the central administration of leptin in ewes during long photoperiod might affect PRL secretion either by acting directly on pituitary lactotrophs or through the central modulation of neurochemical compounds released from hypothalamus. On the other hand, it has been documented that leptin is a very potent prolactin secretagogu in teleost pituitary culture (Tipsmark et al., 2008). 
Similarly, dual action of orexin, inhibitory or stimulatory, on PRL release has been observed in rats (Russell et al., 2000, 2001). It has been documented that orexin A reduces PRL secretion but its action does not involve the hypothalamic dopaminergic neurons in rats (Russell et al., 2000). However, in other experiments it has been shown a stimulatory influence of orexin on PRL release in these animals (Martyńska et al., 2006). Indeed, the orexin antibodies completely suppress the PRL release and preovulatory PRL surge is also dependent upon physiological state (Kohsaka et al., 2001). Injection of orexin in starved rats restored the concentration of PRL to normal levels (Kohsaka et al., 2001).

In sheep, the PRL secretion from pituitary glands in culture under orexin treatment is seasonally dependent. Orexin has a stimulatory influence on PRL release from pituitary glands collected from lactating ewes during long days but it displays opposite effect on this hormone secretion in short day photoperiod (Molik et al., 2008).

Secretion of PRL is also highly dependent upon melatonin secretion from the pineal gland, which activity is fluctuated upon annual cycle of changing day length. This phenomenon is especially evident in seasonally breeding species. In sheep, the short day photoperiod, elevates plasma melatonin concentration which in turn leads to the inhibition in the secretion of PRL (Misztal et al., 1997; Morgan, 2000; Molik et al., 2007; Gomez-Brunet et al., 2008; Morgan and Hazlerigg, 2008; Zięba et al., 2008). Numerous data indicated that prolonged treatment with melatonin (i.e. subcutaneous implants) during the long photoperiod also suppressed PRL secretion either in ewes or rams (Lincoln and Maeda, 1992; Lincoln, 1994; Viguie et al., 1997; Molik et al., 2010). This supports the view that the suppression of prolactin secretion followed by a partial recovery (partial refractoriness) is a normal response to a short-day melatonin signal and that this is due to the action of melatonin in the pituitary gland. Indeed, it has been shown that melatonin inhibits PRL, acting within the pars tuberalis (PT) of the pituitary gland and that a protein factor called tuberalin, which governs both the synthesis and release of prolactin, participates in this mechanism (Morgan, 2000). A long-duration melatonin signal from short days, or a continuous melatonin signal from a melatonin implant, may suppress prolactin secretion by inhibiting the release of tuberalin from the PT. The refractory response could be due to the reduced responsiveness of the melatonin target cells in the pituitary and to the partial recovery of tuberalin secretion acting to restimulate the lactotrophs (Lincoln and Clarke, 1997). Conversely, the short term melatonin infusion into the third ventricle of the brain has been shown to stimulate PRL release in anoestrous ewes (Misztal et al., 1997).

\section{Factors stimulating prolactin release}

Thyrotropin-releasing hormone (TRH) is one of the earliest proposed candidates of hypothalamic origin that stimulates secretion of prolactin from the anterior pituitary gland (Neil and Nagy, 1994; Freeman et al., 2000). TRH has been shown to potentiate PRL release from lactotrophs in a dose-dependent manner both in vitro and in vivo experiments (Bowers et al., 1971; Tashjian et al., 1971; Blake, 1974). It can successfully promote pituitary PRL secretion in oestrogen-primed male rats (Piercy and Shin, 1980), but not in normal male or lactating female (Grosvenor and Mena, 1980; Piercy and Shin, 1980; Riskind et al., 1984). The concentration of TRH in portal blood is slightly elevated during the afternoon of proestrus (Fink et al., 1982) and passive immunoneutralization of endogenous TRH (administration of TRH antiserum) has been reported to partially inhibit (Koch et al., 1977) or delay the onset (Horn et al., 1985) of the proestrus PRL surge and attenuate the suckling-induced prolactin response (De Greef et al., 1987). However, TRH antiserum only slightly decreases prolactin-releasing activity of the hypothalamic extract (Boyd, 1976).

The major site of TRH action is at the pituitary level and is related to its well-established role as a prolactin releasing hormone, although TRH may also affect PRL secretion by acting within the central nervous system (Freeman et al., 2000). It has been documented that central administration of TRH inhibits PRL secretion (Ohta et al., 1985), most probably through the stimulation of TIDA neurons (Ikegami et al., 1992). The existence of TRH-immunopositive neural projections from the paraventricular nucleus to the arcuate nucleus (Brownstein et al., 1982) suggests a possibility of a direct TRH/ dopamine interaction at the level of the hypothalamus. Furthermore, the literature data showing that transient dopamine antagonism (Haisenleder et al., 1991) or this hormone withdrawal (Martinez De La Escalera and Weiner, 1990) increases the stimulatory effect of TRH on PRL secretion. It should be noted that in physiological conditions the lactotrophs are exposed to reducing concentrations of dopamine, but not for the complete this hormone absence, thus the interpretation of presented data must be approached with a caution.

Recently much attention is paid to a group of peptides that have been identified in mammals (Hinuma et al., 1998; Iijima et al., 1999; Fuji et al., 
1999; Maruyama et al., 1999; Ibata et al., 2000), birds (Tachibana et al., 2011), fishes (Fujimoto et al., 1998; Satake et al., 1999; Moriyama et al., 2002; Seale et al., 2002; Sakamoto et al., 2005), amphibians (Sakamoto et al., 2006) as the prolactin releasing peptides (PrRPs). These animals have several forms of PrRPs with different numbers of amino acids $(20,25,31,32,37)$ and different effects on prolactin release (Tachibana et al., 2011).

In rats the PrRPs-31 stimulates exocytosis of prolactin selectively from type II and type III lactotrophs but not from type I PRL-producing cells (Christian et al., 2007). These results indicate that respective receptors and signalling cascades required inducing PRL release. However, there are no still published results regarding the PrRPs-31 receptor expression in lactotroph subtypes (Christian et al., 2007). On the other hand, it is well documented, that not all pituitary lactotrophs in rats express TRH receptors, suggesting the functional heterogeneity of these cells (Christian et al., 2007). TRH receptors have been identified on type II and type III of lactotrophs but not any labelling was evident on type I. Other studies have revealed that the stimulatory influence of PrRPs-31 on PRL release in rats is rather low compared to TRH or VIP (Samson et al., 1998; Curlewis et al., 2002; Swinnen et al., 2005; Christian et al., 2007).

The stimulatory effect of PrRPs-31 on PRL secretion was documented in vitro studies on dispersed pituitary cells taken from lactating rats (Hinuma et al., 1998) and in vivo in male and female rats (Matsumoto et al., 1999). Other investigators, in turn, have no been able to confirm this effect on PRL release in the experiments both: in vivo - in male or female rats (Jarry et al., 2000; Seal et al., 2000) and in vitro - on cells collected from lactating and virgin females (Samson et al., 2000); only high concentration of PrRPs-31 was capable to increase PRL release from dispersed lactotrophs derived from virgin female rats (Samson et al., 1998).

It should be noted that the PrRPs-31 action on PRL release may be species-specific. The PrRPs-31 has no stimulatory effect on PRL release in sheep (Curlewis et al., 2002), but it is essential for secretion of this hormone in teleost fish (Sakamoto et al., 2003). Chicken PrRPs-31/32 increases plasma PRL concentration in chicks when administered peripherally whereas infused centrally decreases PRL release, suggesting that in these animals PrRPs-31/32 has distinct effect on PRL secretion between tissue (Tachibana et al., 2011). It is likely, that the PrRPs-31/32 in the chicken brain might function as a feedback regulator of PRL release. These differences, at least in part, might be caused by differences in the distribution of PrRPs and their receptors. It is very possible, given a fact a distinct tissue distribution for both the PrRP peptide and receptor messenger RNAs in rats (Fuji et al., 1999; Roland et al., 1999). In RT-PCR analysis, rat PrRP receptor mRNA was detected in the central nervous system, and the highest expression was detected in the pituitary gland. In addition, in situ hybridization revealed that rat PrRP receptor mRNA was highly expressed in the anterior lobe of the pituitary. On the other hand, rat PrRP mRNA was most abundantly expressed in the medulla oblongata, while significant levels of expression were widely detected in other tissues (Fuji et al., 1999).

Similarly, angiotensin II, oxytocin, ATP and acetylocholine are implicated in stimulatory influence on PRL release (Ben-Jonathan and Hnasko, 2001). The stimulatory action of serotonin (5-HT) on PRL release involves $5 \mathrm{HT}_{2 \mathrm{~A}}, 5 \mathrm{HT}_{2 \mathrm{C}}$ and $5 \mathrm{HT}_{3 \mathrm{C}}$ receptor subtypes (Balsa et al., 1998). The current opinion is that 5-HT affects PRL secretion primarily by stimulating the release of prolactin releasing factors (Ben-Jonathan and Hnasko, 2001). Opioid peptide stimulates also PRL release by inhibiting the TIDA neurons or promotes salsolinol action (Ben-Jonathan and Hnasko, 2001; Misztal et al., 2010b). GABA appears to play a role in the control of basal and diurnal changes of TIDA neurons activity and contributes to increase PRL secretion (Lee and Pan, 2001).

Suckling is a one among many other powerful stimulators for PRL secretion in mammals (Grattan, 2002; Misztal et al., 2008, 2010a). The stimulatory action of suckling on PRL release might result from many processes, which most important are two: a decrease of inhibitory effect of DA and other inhibitors of PRL release, and an increase of stimulatory secretagogue on lactotrophs and/or both of these events (Ben-Jonathan and Hnasko, 2001; Stojilkovic et al., 2010; Tachibana et al., 2011).

Studies on rats have shown that the dopaminergic system in the hypothalamus during late pregnancy has reduced ability to respond to PRL (Grattan and Averill, 1995; Andrews et al., 2001) and that this impaired negative feedback is continued into lactation (Arbogast and Voogt, 1998; Anderson et al., 2006), allowing the maintenance of increased PRL secretion to promote lactogenesis.

Subsequent works have indicated that the opioid peptides might be involved in this process. Indeed, the opioid peptides reduce hypothalamic 
<smiles>NCCc1ccc(O)c(O)c1</smiles>

dopamine<smiles>CC1NCCc2cc(O)c(O)cc21</smiles>

salsolinol
Figure 1. The structural formulas of dopamine and salsolinol

dopaminergic system activity in rats by marked suppression of tyrosine hydroxylase gene expression during lactation (Arbogast and Voogt, 1998). More recently, attention has been paid for a DA-derived product, salsolinol, (1-methyl-6,7-dihydroxy-1,2,3,4-tetrahydroisoquinoline, Figure 1), which stimulatory properties for prolactin secretion were described either in rodents or ruminants (Toth et al., 2001, 2002; Hashizume et al., 2008 a,b; Misztal et al., 2008, 2010a, Górski et al., 2010; Hasiec et al., 2012)

In lactating ewes, the extracellular concentration of salsolinol in the infundibular nucleus/median eminence (IN/ME) increased in response to suckling stimulus and was closely related to suckling-induced increase in PRL secretion (Misztal et al., 2008). No concentration of DA was detected in the perfusates collected from the IN/ME during this early period of lactation (4/5 week). Since the endogenous opioid peptides (EOP) antagonists, naloxone or naloxonazine, infused into the third ventricle of the brain of nursing sheep, diminished the concentration of salsolinol in the IN/ME and increased the release of DA (Misztal et al., 2010b), it suggested that changes in the DA/salsolinol ratio in the hypothalamic dopaminergic system resulted from the transformation of DA to salsolinol and the EOP are a base of this process. Moreover, the infusion of salsolinol into the third brain ventricle stimulated both the PRL release in lactating ewes (Górski et al., 2010) and expression of PRL mRNA in lactating ewes after $48 \mathrm{~h}$ of lamb weaning (Hasiec et al., 2012). In turn, the infusion of 1-MeDIQ, a structural analogue of salsolinol, inhibited basal PRL release in nursing ewes and reduced suckling-induced prolactin surge (Misztal et al., 2010a). 1-MeDIQ was proved to be very potent inhibitor of salsolinolinduced PRL release and blocked PRL release in suckling and stressed lactating rats (Bodnar et al., 2004). Since the stimulatory action of salsolinol on PRL release might occur at the hypothalamic as well as at the pituitary level (Toth et al., 2001, 2002; Hashizume et al., 2008a; Misztal et al., 2008, 2010b; Górski et al., 2010; Hasiec et al., 2012) it is assumed that salsolinol can act indirectly through modulation of the dopaminergic system in the hypothalamus as well as directly through stimulation of specific receptors in pituitary gland. Although exact salsolinol receptors have not been found on prolactin cells the stimulatory effect of salsolinol on PRL release from lactotrophs has been observed in the studies using cell culture systems in rats (Toth et al., 2001) and young 7-8-month old heifers (Hashizume et al., 2008a) but not on 1 month old animals (Hashizume et al., 2009). Salsolinol stimulated prolactin secretion in hypophysectomized rats bearing anterior lobe transplants under the kidney capsule (Toth et al., 2001). Recent in vivo and in vitro studies on the influence of salsolinol on PRL secretion revealed, that it increases PRL mRNA expression in the anterior pituitary gland, thus suggesting that salsolinol is involved in the stimulation of PRL biosynthesis (Hasiec et al., 2012).

Studies curried out for comparison the characteristics of the PRL-releasing response to salsolinol and TRH revealed that in ruminants the mechanism(s) of the salsolinol induced release of PRL is different from the mechanism(s) of action of TRH (Hashizume et al., 2009). However, the relation between salsolinol and TRH has not fully elucidated and requires further research.

In summary, original research results presented briefly in this review demonstrate that the PRL producing cells are non-homologous group and they might secrete PRL, or GH and both of them. Most PRL cells are also heterogenous with respect to basal hormone release, electrical activity and responsiveness to secretagogues, depending upon physiological stage, place their action and gender. PRL is involved in regulation of many physiological functions displaying multimodal action as a growth factor, neurotransmitter, immunoregulator or hormone and is upon the regulation of many central and peripheral factors to keep its secretion on the sustainable level.

\section{References}

Accorsi P.A., Munno A., Gamberoni M., Viggiani R., De Ambrogi M., Tamanini C., Seren E., 2007. The role of leptin on growth hormone and prolactin secretion by bovine pituitary explants. J. Dairy Sci. 90, 1683-1691

Ahlquist J.A., Fahie-Wilson M.W., Cameron J., 1998. Variable detection of macroprolactin: a cause of apparent change in serum prolactin levels. Clin. Endocrinol. 48, 123-124

Anderson S.T., Barclay J.L., Fanning K.J., Kusters D.H., Waters M.J., Curlewis J.D., 2006. Mechanisms underlying the diminished sensitivity to prolactin negative feedback during lactation: reduced STAT5 signaling and up-regulation of cytokine-inducible $\mathrm{SH} 2$ domain-containing protein $(\mathrm{CIS})$ expression in tuberoinfundibular dopaminergic neurons. Endocrinology $147,1195-1202$ 
Andrews Z.B., Kokay I.C., Grattan D.R., 2001. Dissociation of prolactin secretion from tuberoinfundibular dopamine activity in late pregnant rats. Endocrinology 142, 2719-2724

Anthony P.K., Stoltz R.A., Pucci M.L., Powers C.A., 1993. The 22 K variant of rat prolactin: evidence for identity of prolactin-(!$173)$, storage in secretory granules, and regulated release. Endocrinology 132, 806-814

Arbogast L.A., Voogt J.L., 1998. Endogenous opioid peptides contribute to suckling-induced prolactin release by suppresing tyrosine-hydroxylase activity and messenger ribonucleic acid levels in tuberoinfundibular dopaminergic neurons. Endocrinology 139, 2857-2862

Baldocchi R.A., Tan L., Nicoll C.S., 1992. Processing of rat prolactin by rat tissue explants and serum in vitro. Endocrinology 130 , 1653-1659

Balsa J.A., Sanchez-Franco F., Pazos F., Lara J.I., Lorenzo M.J., Maldonado G., Cacicedo L., 1998. Direct action of serotonin on prolactin, growth hormone, corticotropin and luteinizing hormone release in cocultures of anterior and posterior pituitary lobes: autocrine and/or paracrine action of vasoactive intestinal peptide. Neuroendocrinology 68, 326-333

Ben-Jonathan N., Hnasko R., 2001. Dopamine as a prolactin (PRL) inhibitor. Endocr. Rev. 22, 724-763

Ben-Jonathan N., Mershon J.L., Allen D.L., Steinmetz R.W., 1996. Extrapituitary prolactin: distribution, regulation, functions, and clinical aspects. Endocr. Rev. 17, 639-669

Bewley T.A., Li C. H., 1972. Circular dichroism studies on human pituitary growth hormone and ovine pituitary lactogenic hormone. Biochemistry 11, 884-888

Blake C.A., 1974. Stimulation of pituitary prolactin and TSH release in lactating and proestrous rats. Endocrinology 94, 503-508

Bodnar I., Mravec B., Kubovcakova L., Toth E.B., Fulop F., Fekete M.I., Kvetnansky R., Nagy G.M., 2004. Stress- as well as suckling-induced prolactin release is blocked by a structural analogue of the putative hypophysiotrophic prolactin-releasing factor, salsolinol. J. Neuroendocrinol. 16, 208-213

Bole-Feysot C., Goffin V., Edery M., Binart N., Kelly P.A., 1998. Prolactin (PRL) and its receptor: actions signal transduction pathways and phenotypes observed in PRL receptor knockout mice. Endocr. Rev. 19, 225-268

Bonhoff A., Vuille J.C., Gomez F., Gellersen B., 1995. Identification of macroprolactin in a patient with asymptomatic hyperprolactinemia as a stable PRL-IgG complex. Exp. Clin. Endocrinol Diab. 103, 252-255

Bowers C.Y., Friesen H.G., Hwang P., Guyda H.J., Folkers K., 1971. Prolactin and thyrotropin release in man by synthetic pyroglutamyl-histidyl-prolinamide. Biochem. Biophys. Res. Commun. 45, 1033-1041

Boyd A.E., 1976. Prolactin-releasing factor (PRF) in porcine hypothalamic extract distinct from TRH. Endocrinology 99, 861-871

Brownstein M.J., Eskay R.L., Palkovits M., 1982. Thyrotropin releasing hormone in the median eminence is in processes of paraventricular nuclelus neurons. Neuropeptides 2, 197-201

Caccavelli L., Cussac D., Pellegrini I., Audinot V., Jaquet P., Enjalbert A., 1992. D2 dopaminergic receptors: normal and abnormal transduction mechanisms. Horm. Res. 38, 78-83
Casabiell X., Robertson M.C., Friesen H.G., Casanueva F.F., 1989. Cleaved prolactin and its $16 \mathrm{~K}$ fragment are generated by an acid protease. Endocrinology 125, 1967-1972

Cavaco B., Leite V., Santos M.A., Arranhado E., Sobrinho L.G., 1995. Some forms of big big prolactin behave as a complex of monomeric prolactin with an immunoglobulin $\mathrm{G}$ in patients with macroprolactinemia or prolactinoma. J. Clin. Endocrinol. Metab. 80, 2342-2346

Christian H.C., Chapman L.P., Morris J.F., 2007. Thyrotrophin-releasing hormone, vasoactive intestinal peptide, prolactin-releasing peptide and dopamine regulation of prolactin secretion by different lactotroph morphological subtypes in the rat. J. Neuroendocrinol. 19, 605-613

Clapp C., Weiner R.I., 1992. A specific, high affinity, saturable binding site for the 16-kilodalton fragment of prolactin on capillary endothelial cells. Endocrinology 130, 1380-1386

Cooke N.E., Coit D., Shine J., Baxter J.D., Martial J.A., 1981. Human prolactin. CDNA structural analysis and evolutionary comparisons. J. Biol. Chem. 256, 4007-4016

Curlewis J.D., Kusters D.H., Barclay J.L., Anderson S.T., 2002. Prolactin-releasing peptide in the ewe: cDNA cloning, mRNA distribution and effects on prolactin secretion in vitro and in vivo. J. Endocrinol. 174, 45-53

De Greef W.J., Voogt J.L., Visser T.J., Lamberts W.J.S., Van Der Shoot P., 1987. Control of prolactin release induced by suckling. Endocrinology 121, 316-322

DeMaria J.E., Zelena D., Vecsernyes M., Nagy G.M., Freeman M.E., 1998. The effect of neurointermediate lobe denervation on hypothalamic neuroendocrine dopaminergic neurons. Brain Res. 806, 89-94

DeVito W.J., Avakian C., Stone S., 1992. Proteolytic modification of prolactin by the female rat brain. Neuroendocrinology 56 , 597-603

Diver M.J., Ewins D.L., Worth R.C., Bowles S., Ahlquist J.A., Fahie-Wilson M.N., 2001. An unusual form of big, big (macro) prolactin in a pregnant patient. Clin. Chem. 47, 346-348

Ellis M.J., Reed M.R., Livesey J.H., 2007. Cross-reactivities of macroprolactin and big-prolactin in three commercial immunoassays for prolactin: a chromatographic analysis. Clin. Biochem. 40, 1285-1290

Fahie-Wilson M.N., John R., Ellis A.R., 2005. Macroprolactin; high molecular mass forms of circulating prolactin. Ann. Clin. Biochem. 42, 175-192

Fink G., Koch Y., Benaroya N., 1982. Release of thyrotropin releasing hormone into hypophysial portal blood is high relative to other neuropeptides and may be related to prolactin secretion. Brain Res. 243, 186-189

Freeman M.E., Kanyicska B., Lerant A., Nagy G., 2000. Prolactin: structure, function, and regulation of secretion. Physiol. Rev. 80, 1523-1531

Fujii R., Fukusumi S., Hosoya M. et al., 1999. Tissue distribution of prolactin-releasing peptide (PrRP) and its receptor. Regul. Pept. 83, 1-10

Fujimoto M., Takeshita K., Wang X., Takabatake I., Fujisawa Y., Teranishi H., Ohtani M., Muneoka Y., Ohta S., 1998. Isolation and characterization of a novel bioactive peptide, Carassius RFamide (C-RFa), from the brain of the Japanese crucian carp. Biochem. Biophys. Res. Commun. 242, 436-440 
Galoiu S., Kertesz G., Somma C., Coculescu M., Bruce T., 2005. Clinical expression of big-big prolactin and influence of macroprolactinemia upon immunodiagnostic tests. Acta Endocrinologica (Buc) 1, 30-40

Gomez-Brunet A., Santiago-Moreno J., del Campo A., Malpaux B., Chemineau P., Tortonese D.J., Gonzales-Bulnes A., LopezSebastian A., 2008. Endogenous circannual cycles of ovarian activity and changes in prolactin and melatonin secretion in wild and domestic female sheep maintained under a long-day photoperiod. Biol. Reprod. 78, 552-562

Gonzalez L.C., Pinilla L., Tena-Sempere M., Aguilar E., 1999. Leptin (116-130) stimulates prolactin and luteinizing hormone secretion in fasted adult male rats. Neuroendocrinology 70 , 213-220

Górski K., Romanowicz K., Herman A., Molik E., Gajewska A., Tomaszewska-Zaremba D., Misztal T., 2010. The possible involvement of salsolinol and hypothalamic prolactin in the central regulatory processes in ewes during lactation. Reprod. Domest. Anim. 45, 54-60

Grattan D.R., 2002. Behavioural significance of prolactin signalling in the central nervous system during pregnancy and lactation. Reproduction 123, 497-506

Grattan D.R., Averill R.L., 1995. Absence of short-loop autoregulation of prolactin during late pregnancy in the rat. Brain Res. Bull. $36,413-416$

Grosvenor C.E., Mena F., 1980. Evidence that thyrotropin-releasing hormone and a hypothalamic prolactin-releasing factor may function in the release of prolactin in the lactating rat. Endocrinology $107,863-868$

Haisenleder D.J., Gala R.R., Lawson D.M., 1991. The effect of transient dopamine antagonism on thyrotropin-releasing hormone-induced prolactin release in female rats during the estrous cycle. Life Sci. 48, 1911-1918

Hashizume T., Onodera Y., Shida R., Isobe E., Suzuki S., Sawai K., Kasuya E., Nagy G.M., 2009. Characteristics of prolactin-releasing response to salsolinol (SAL) and thyrotropin-releasing hormone (TRH) in ruminants. Domest. Anim. Endocrinol. 36, 99-104

Hashizume T., Shida R., Suzuki S., et al., 2008a. Sansolinol is present in the bovine posterior pituitary gland and stimulates the release of prolactin both in vivo and in vitro in ruminants. Domest. Anim. Endocrinol. 34, 146-152

Hashizume T., Shida R., Suzuki S., Kasuya E., Kuwayama H., Suzuki H., Olah M., Nagy G.M., 2008 b. Interaction between salsolinol (SAL) and thyrotropin-releasing hormone (TRH) or dopamine (DA) on the secretion of prolactin in ruminants. Domest. Anim. Endocrinol. 34, 327-332

Hasiec M., Herman A.P., Molik E., Dobek E., Romanowicz K., Fulom F., Misztal T., 2012. The stimulatory effect of sansolinol on prolactin gene expression within the anterior pituitary of lactating sheep: in vivo and in vitro study. Small Ruminants Res. 102, 202-207

Hattori N., Ishihara T., Ikekubo K., Moridera K., Hino M., Kurahachi H., 1992. Autoantibody to human prolactin in patients with idiopathic hyperprolactinemia. J. Clin. Endocrinol. Metab. 75, 1226-1229

Hinuma S., Habata Y., Fuji R., et al., 1998. A prolactin-releasing peptide in the brain. Nature 393, 272-276

Horn A.M., Fraser H.M., Fink G., 1985. Effects of antiserum to thyrotrophin-releasing hormone on the concentrations of plasma prolactin, thyrotrophin and LH in the pro-oestrous rat. J. Endocrinol. 104, 205-209

Ibata Y., lijima N., Kataoka Y., Kakihara K., Tanaka M., Hosoya M., Hinuma S., 2000. Morphological survey of prolactin-releasing peptide and its receptor with special reference to their functional roles in the brain. Neurosci. Res. 38, 223-230 lijima N., Kataoka Y., Kakihara K., et al., 1999. Cytochemical study of prolactin-releasing peptide (PrRP) in the rat brain. Neuroreport 10, 1713-1716

Ikegami H., Jikihara H., Koike K., Morishige K., Kurachi H., Yamamoto N., Hirota K., Miyake A., Tanizawa O., 1992. Intraventricular administration of thyrotropin-releasing hormone (TRH) suppresses prolactin secretion and synthesis: a possible involvement of dopamine release by TRH from rat hypothalamus. J. Endocrinol. 133, 59-66

Jackson R.D., Wortsman J., Malarkey W.B., 1985. Characterization of a large molecular weight prolactin in women with idiopathic hyperprolactinemia and normal menses. J. Clin. Endocrinol. Metab. 61, 258-264

Jarry H., Heuer H., Schomburg L., Bauer K., 2000. Prolactin-releasing peptides do not stimulate prolactin release in vivo. Neuroendocrinology $71,262-267$

Kanyicska B., Burris T.P., Freeman M.E., 1991. Endothelin-3 inhibits prolactin and stimulates $\mathrm{LH}, \mathrm{FSH}$ and TSH secretion from pituitary cell culture. Biochem. Biophys. Res. Commun.174, 338-343

Kanyicska B., Livingstone J.D., Freeman M.E., 1995. Long term exposure to dopamine reverses the inhibitory effect of endothelin-1 on prolactin secretion. Endocrinology 136, 990-994

Kline J.B., Clevenger C.V., 2001. Identification and characterization of the prolactin-binding protein in human serum and milk. J. Biol. Chem. 276, 24760-24766

Koch Y., Goldhaber G., Fireman I., Zor U., Shani J., 1977. Suppression of prolactin and thyrotropin secretion in the rat by antiserum to thyrotropin-releasing hormone. Endocrinology 100, 1476-1478

Kohsaka A., Watanobe H., Kakizaki Y., Suda T., Schioth H.B., 2001. A significant participation of orexin- $A$, a potent orexigenic peptide, in the preovulatory luteinizing hormone and prolactin surges in the rat. Brain Res. 898, 166-170

Lamberts S.W., Macleod R.M., 1990. Regulation of prolactin secretion at the level of the lactotroph. Physiol. Rev. 70, 279-318

Leanos A., Pascoe D., Fraga A., Blanco-Favela F., 1998. Anti-prolactin autoantibodies in systemic lupus erythematosus patients with associated hyperprolactinemia. Lupus 7, 398-403

Lee T.Y., Pan J.T., 2001. Involvement of central GABAergic neurons in basal and diurnal changes of tuberoinfundibular dopaminergic neuronal activity and prolactin secretion. Life Sci. 68, 1965-1975

Leite V., Cosby H., Sobrinho L.G., Fresnoza M.A., Santos M.A., Friesen H.G., 1992. Characterization of big, big prolactin in patients with hyperprolactinaemia. Clin. Endocrinol. 37, 365-372

Lew A.M., Elsholtz H.P., 1995. A dopamine-responsive domain in the $\mathrm{N}$-terminal sequence of Pit-1. Transcriptional inhibition in endocrine cell types. J. Biol. Chem. 70, 7156-7160

Lincoln G., 1994. Effects of placing micro-implants of melatonin in the pars tuberalis, pars distalis and the lateral septum of the forebrain on the secretion of FSH and prolactin, and testicular size in rams. J. Endocrinol. 142, 267-276

Lincoln G.A., Clarke J., 1997. Refractoriness to a static melatonin signal develops in the pituitary gland for the control of prolactin secretion in the ram Biol. Reprod. 57, 460-467

Lincoln G.A., Maeda K., 1992. Effects of placing micro-implants of melatonin in the mediobasal hypothalamus and preoptic area on the secretion of prolactin and beta-endorphin in rams. J. Endocrinol. 134, 437-448

Livingstone J.D., Lerant A., Freeman M.E., 1998. Ovarian steroids modulate responsiveness to dopamine and expression of G-proteins in lactotropes. Neuroendocrinology 68, 172-179

Mai L.M., Pan J.T., 1995. Bombesin acts in the suprachiasmatic nucleus to affect circadian changes in tuberoinfundibular dopaminergic neuron activity and prolactin secretion. Endocrinology 136, 4163-4167 
Martinez De La Escalera G., Weiner R.I., 1990. Transient dopamine withdrawal differentially potentiates thyrotropin releasing hormone-induced release of prolactin of various ages. Neuroendocrinology $51,694-699$

Martyńska L., Polkowska J., Wolińska-Witort E., Chmielowska M., Wasilewska-Dziubińska E., Bik W., Baranowska B., 2006. Orexin $A$ and its role in the regulation of the hypothalamo-pituitary axes in the rat. Reprod. Biol. 6, 29-35

Maruyama M., Matsumoto H., Fujiwara K., Kitara C., Hinuma S., Onda H., Fujino M., Inoue K., 1999. Immunocytochemical localization of prolactin-releasing peptide in the rat brain. Endocrinology $140,2326-2333$

Matsumoto H., Noguchi J., Horikoshi Y., Kawamata Y., Kitada C., Hinuma S., Onda H., Nishimura O., Fujino M., 1999. Stimulation of prolactin release by prolactin-releasing peptide in rats. Biochem. Biophys. Res. Commun. 259, 321-324

McCann S.M., Vijayan E., 1992. Control of anterior pituitary hormone secretion by neurotensin. Ann. NY Acad. Sci. 668, 287-297

Mena F., Navarro N., Castilla A., Morales T., Fiordelisio T., Carabez A., Aguilar M.B., Huerta-Ocampo I., 2010. Prolactin released in vitro from the pituitary of lactating, pregnant, and steroid-treated female or male rats stimulates prolactin secretion from pituitary lactotropes of male rats. Neuroendocrinology 91, 77-93

Miller W.L., Eberhardt N.L., 1983. Structure and evolution of the growth hormone gene family. Endocr. Rev. 4, 97-130

Misztal T., Górski K., Tomaszewska-Zaremba D., Fülöp F., Romanowicz K., 2010a. Effects of a structural analogue of salsolinol, $1-\mathrm{MeDIQ}$, on pituitary prolactin release and dopaminergic activity in the mediobasal hypothalamus in nursing sheep. Brain. Res. 1307, 72-77

Misztal T., Górski K., Tomaszewska-Zaremba D., Molik E., Romanowicz K., 2008. Identification of salsolinol in the mediobasal hypothalamus of lactating ewes and its relation to suckling-induced prolactin and GH release. J. Endocrinol. 198, 83-89

Misztal T., Romanowicz K., Barcikowski B., 1997. Natural and melatonin-stimulated changes in the circadian rhythm of prolactin secretion in the ewe during seasonal anestrus. Neuroendocrinology 66, 360-367

Misztal T., Tomaszewska-Zaremba D., Górski K., Romanowicz K., $2010 \mathrm{~b}$. Opioid-salsolinol relationship in the control of prolactin release during lactation. Neuroscience 170, 1165-1171

Molik E., Misztal T., Romanowicz K., Wierzchoś E., 2007. Dependence of the lactation duration and efficiency on the season of lambing in relation to the prolactin and melatonin secretion in ewes. Livest. Sci. 107, 220-226

Molik E., Misztal T., Romanowicz K., Zięba D.A., 2010. The effect of melatonin on prolactin and growth hormone secretion in ewes under different photoperiods, during the early post partum period. Small Ruminant Res. 94, 137-141

Molik E., Zięba D.A., Misztal T., Romanowicz K., Wszoła M., Wierzchoś E., Nowakowski M., 2008. The role of orexin A in the control of prolactin and growth hormone secretions in sheepin vitro study. J. Physiol. Pharmacol., Suppl. 9: 91, 100

Moore R.Y., Speh J.C., Leak R.K., 2002. Suprachiasmatic nucleus organization. Cell Tissue Res. 309, 89-98

Morgan P.J., 2000. The pars tuberalis: the missing link in the photoperiodic regulation of prolactin secretion? J. Neuroendocrinol. $12,287-295$

Morgan P.J., Hazlerigg D.G., 2008. Photoperiodic signalling through the melatonin receptor turns full circle. J. Neuroendocrinol. $20,820-826$

Morin L.P., Shivers K.Y., Blanchard J.H., Muscat L., 2006. Complex organization of mouse and rat suprachiasmatic nucleus. Neuroscience 137, 1285-1297
Moriyama S., Ito T., Takahashi A., Amano M., Sower S.A., Hirano T., Yamamori K., Kawauchi H., 2002. A homolog of mammalian PRL-releasing peptide (fish arginyl-phenylalanyl-amide peptide) is a major hypothalamic peptide of PRL release in teleost fish. Endocrinology 143, 2071-2079

Nagy E., Berczi I., 1991. Hypophysectomized rats depend on residual prolactin for survival. Endocrinology 128, 2776-2784

Neil J.D., Nagy G.M., 1994. Prolactin secretion and its control. In: E. Knobil, J.D. Neil (Editors). New York. Raven Press, pp. 357-388

Nonaka S., Hashizume T., Yamashiba T., 2007. Effect of leptin peptide amine on the release of luteinizing hormone and prolactin from cultured porcine anterior pituitary cells. Anim. Sci. J. 77, 47-52

Ohta H., Kato Y., Matsushita N., Shimatsu A., Kabayama Y., Imura H., 1985. Central inhibitory action of TRH on prolactin secretion in the rat. Proc. Soc. Exp. Biol. Med. 179, 9-12

Pacilio M., Migliaresi S., Meli R., Ambrosone L., Bigliardo B., Di Carlo R., 2001. Elevated bioactive prolactin levels in systemic lupus erythematosus--association with disease activity. J. Reumatol. 28, 2216-2221

Palm J.T., van der Beek E.M., Swarts H.J., van der Vliet J., Wiegant V.M., Buijs R.M., Kalsbeek A., 2001. Control of the estradiol-induced prolactin surge by the suprachiasmatic nucleus. Endocrinology 142, 2296-2302

Pan J.T., Tian Y., Lookingland K.J., Moore K.E., 1992. Neurotensin-induced activation of hypothalamic dopaminergic neurons is accompanied by a decrease in pituitary secretion of prolactin and alpha-melanocyte-stimulating hormone. Life Sci. 50, 2011-2017

Piercy M., Shin S.H., 1980. Comparative studies of prolactin secretion in estradiol-primed and normal male rats induced by ether stress, pimozide and TRH. Neuroendocrinology 31, 270-275

Piketly M-L., Laneelin F., Poirier-Begue E., Coussieu C., 2002. Le dosage de la prolactine at ses pieges. Rep. Hum. Hormones $15,7-16$

Poletini M.O., Kennett J.E., McKee D.T., Freeman M.E., 2010. Central clock regulates the cervically stimulated prolactin surges by modulation of dopamine and vasoactive intestinal polypeptide release in ovariectomized rats. Neuroendocrinology 91 , 179-188

Powers C.A., Hatala M.A., 1990. Prolactin proteolysis by glandular kallikrein: in vitro reaction requirements and cleavage sites, and detection of processed prolactin in vivo. Endocrinology 127, 1916-1927

Rentier-Delrue F., Swennen D., Prunet P., Lion M., Martial J.A., 1989. Tilapia prolactin: molecular cloning of two CDNAs and expression in Escherichia coli. DNA 8, 261-270

Riskind P.N., Millard W.J., Martin J.B., 1984. Evidence that thyrotropin-releasing hormone is not a major prolactin-releasing factor during suckling in the rat. Endocrinology 115, 312-316

Roland B.L., Sutton S.W., Wilson S.J., Luo L., Pyati J., Huvar R., Erlander M.G., Lovenberg T.W., 1999. Anatomical distribution of prolactin-releasing peptide and its receptor suggests additional functions in the central nervous system and periphery. Endocrinology 140, 5736-5745

Russell S.H., Kim M.S., Small C.J., Abbott C.R., Morgan D.G., Taheri S., Murphy K.G., Todd J.F., Ghatei M.A., Bloom S.R., 2000. Central administration of orexin A suppresses basal and domperidone stimulated plasma prolactin. J. Neuroendocrinol. 12, 1213-1218

Russell S.H., Small C.J., Kennedy A.R., Stanley S.A., Seth A., Murphy K.G., Taheri S., Ghatei M.A., Bloom S.R.,2001. Orexin A interactions in the hypothalamo-pituitary gonadal axis. Endocrinology 142, 5294-5302 
Sakamoto T., Amano M., Hyodo S., Moriyama S., Takahashi A., Kawauchi H., Ando M., 2005. Expression of prolactin-releasing peptide and prolactin in the euryhaline mudskippers (Periophthalmus modestus): prolactin-releasing peptide as a primary regulator of prolactin. J. Mol. Endocrinol. 34, 825-834

Sakamoto T., Fujimoto M., Ando M., 2003. Fishy tales of prolactin-releasing peptide. Int. Rev. Cytol. 225, 91-130

Sakamoto T., Oda A., Yamamoto K., Kaneko M., Kikuyama S., Nishikawa A., Takahashi A., Kawauchi H., Tsutsui K., Fujimoto M., 2006. Molecular cloning and functional characterization of a prolactin-releasing peptide homolog from Xenopus laevis. Peptides 27, 3347-3351

Sam S., Frohman L.A., 2008. Normal physiology of hypothalamic pituitary regulation. Endocrinol. Metab. Clin. N. Amer. 37, 1-22

Samson W.K., Resch Z.T., Murphy T.C., 2000. A novel action of the newly described prolactin-releasing peptides: cardiovascular regulation. Brain Res. 858, 19-25

Samson W.K., Resch Z.T., Murphy T.C., Chang J.K., 1998. Gender-biased activity of the novel prolactin releasing peptides: comparison with thyrotropin releasing hormone reveals only pharmacologic effects. Endocrine 9, 289-291

Samson W.K., Skala K.D., 1992. Comparison of the pituitary effects of the mammalian endothelins: vasoactive intestinal contractor (endothelinB, rat endothelin-2) is a potent inhibitor of prolactin secretion. Endocrinology 130, 2964-2970

Samson W.K., Skala K.D., Alexander B.D., Huong F.L., 1990. Pituitary site of action of endothelin: selective inhibition of prolactin release in vitro. Biochem. Biophys. Res. Commun. 169, 737-743

Satake H., Minakata H., Wang X., Fujimoto M., 1999. Characterization of a cDNA encoding a precursor of Carassius RFamide, structurally related to a mammalian prolactin-releasing peptide. FEBS Lett. 446, 247-250

Seal L.J., Small C.J., Kim M.S., Stanley S.A., Taheri S., Ghatei M.A., Bloom S.R., 2000. Prolactin releasing peptide (PrRP) stimulates luteinizing hormone $(\mathrm{LH})$ and follicle stimulating hormone (FSH) via a hypothalamic mechanism in male rats. Endocrinology 141, 1909-1912

Seale A.P., Itoh T., Moriyama S., Takahashi A., Kawauchi H., Sakamoto T., Fujimoto M., Riley L.G., Hirano T., Grau E.G., 2002. Isolation and characterization of a homologue of mammalian prolactin-releasing peptide from the tilapia brain and its effect on prolactin release from the tilapia pituitary. Gen. Comp. Endocrinol. 125, 328-339

Sinha Y.N., 1995. Structural variants of prolactin: occurrence and physiological significance. Endocr. Rev. 16, 354-369

Stojilkovic S.S., Tabak J., Bertram R., 2010. Ion channels and signaling in the pituitary gland. Endocr. Rev. 31, 845-915
Swinnen E., Boussemaere M., Denef C., 2005. Stimulation and inhibition of prolactin release by prolactin-releasing Peptide in rat anterior pituitary cell aggregates. J. Neuroendocrinol. 17, 379-386

Tachibana T., Moriyama S., Takahashi A., Tsukada A., Oda A., Takeuchi S., Sakamoto T., 2011. Isolation and characterisation of prolactin-releasing peptide in chicks and its effect on prolactin release and feeding behaviour. J. Neuroendocrinol. 23, 74-81. doi: $10.1111 / j$

Tashjian A.H.J., Barowsky N.J., Jensen D.K., 1971. Thyrotropin releasing hormone: direct evidence for stimulation of prolactin production by pituitary cells in culture. Biochem. Biophys. Res. Commun 43, 516.-523

Tipsmark C.K., Strom C.N., Bailey S.T., Borski R.J., 2008. Leptin stimulates pituitary prolactin release through an extracellular signal-regulated kinase-dependent pathway. J. Endocrinol. 196, 275-281

Tóth B.E., Bodnár I., Homicskó K., Fülöp F., Fekete M.J.K., Naggy G.M., 2002. Physiological role of salsolinol: its hypophysiotrophic function in the regulation of pituitary prolactin secretion. Neurotoxicol. Teratol. 24, 655-666

Tóth B.E., Homicskó K., Radnai B., et al., 2001. Salsolinol is a putative endogenous neuro-intermediate lobe prolactin-releasing factor. J. Neuroendocrinol. 13, 1042-1050

Viguié C., Thibault J., Thiéry J.C., Tillet Y., Malpaux B., 1997. Characterization of the short day-induced decrease in median eminence tyrosine hydroxylase activity in the ewe: temporal relationship to the changes in luteinizing hormone and prolactin secretion and short day-like effect of melatonin. Endocrinology 138, 499-506

Walker W.H., Fitzpatrick S.L., Barrera-Saldaña H.A., Resendez-Perez D., Saunders G.F., 1991. The human placental lactogen genes: structure, function, evolution and transcriptional regulation. Endocr. Rev. 12, 316-328

Watanobe H., Schioth H.B., Wikberg J.E., Suda T., 1999. The melanocortin 4 receptor mediates leptin stimulation of luteinizing hormone and prolactin surges in steroid-primed ovariectomized rats. Biochem. Biophys. Res. Commun. 257, 860-864

Yasuda A., Miyazima K., Kawauchi H., Peter R.E., Lin H.R., Yamaguchi K., Sano H., 1987. Primary structure of common carp prolactins. Gen. Comp. Endocrinol. 66, 280-290

Yu W.H., Kimura M., Walczewska A., Karanth S., McCann S.M., 1997. Role of leptin in hypothalamic-pituitary function. Proc. Nat. Acad. Sci. USA 94, 1023-1028

Zięba D.A., Szczesna M., Klocek-Gorka B., Molik E., Misztal T., Williams G.L., Romanowicz K., Stępień E., Keisler D.H., Murawski M., 2008. Seasonal effects of central leptin infusion on secretion of melatonin and prolactin and on SOCS-3 gene expression in ewes. J. Endocrinol. 198, 147-155 